\title{
MENINGKATKAN KEMAMPUAN REPRESENTASI MATEMATIS PADA MATERI INTEGRAL LUAS SISWA KELAS XII TEK A SMK NEGERI 1 CIMAHI MENGGUNAKAN PENDEKATAN METAKOGNITIF
}

\author{
Endang Rivai \\ Sekolah Menengah Kejuruan Negeri 1 Cimahi \\ endang.april66@gmail.com
}

\begin{abstract}
ABSTRAK
Penelitian ini adalah penelitian tindakan kelas. Masalah yang dirumuskan dalam penelitian ini adalah mengetahui apakah dengan menggunakan pendekatan keterampilan metakognitif kemampuan representasi matematis siswa pada materi integral luas dapat ditingkatkan. Penelitian ini dilaksanakan pada siswa Kelas XII TEK A SMK Negeri 1 Cimahi tahun pelajaran 2018/2019 dengan jumlah siswa 36 orang. Instrument yang digunakan adalah tes hasil belajar sebagai tes kemampuan representasi matematik siswa, untuk tes awal (sebelum tindakan), tes siklus I dan tes siklus II (setelah pemberian tindakan), dan lembar observasi bagi guru dan bagi siswa untuk kondisi pelaksanaan tindakan. Prosedur penelitian ini terdiri dari: (1)perencanaan, (2)pelaksanaan tindakan, (3)observasi dan evaluasi dan (4) refleksi.. Berdasarkan hasil penelitian tindakan kelas yang telah dilakukan, pada materi integral luas siswa kelas XII TEK A SMK Negeri 1 Cimahi, bahwa pembelajaran materi integral luas dengan pendekatan metakognitif dapat meningkatkan kemampuan representasi matematis siswa. Hal ini dapat terlihat dari hasil tes kemampuan representasi matematis siswa yang mengalami peningkatan. Hasil tes kemampuan representasi matematis pada tes awal hanya memiliki rata rata kelas 42,60. Pada siklus I, hasil tes meningkat cukup signifikan menjadi 52,19. Pada siklus II mengalami perbaikan lagi dan rata-rata kelas untuk nilai tes kemampuan pemecahan masalah matematik siswa mencapai 58,59.
\end{abstract}

Kata Kunci : Representasi Matematis, siswa, SMK

\section{PENDAHULUAN}

Pentingnya pendidikan di era ini dilatarbelakangi oleh semakin berkembang pesatnya persaingan global. Dengan demikian, agar individu tidak tertinggal dalam menghadapi tantangan zaman, maka individu tersebut haruslah memiliki kualitas yang salah satunya merupakan kemampuan berpikir.

Menurut NCTM atau National Council of Teachers Mathematics (Maryanti, 2012:5), “Terdapat lima kompetensi dalam pembelajaran matematika, yaitu: pemecahan masalah matematik (mathematical problem solving), komunikasi matematik (mathematical communication), penalaran matematik (mathematical reasoning), koneksi matematik (mathematical connection), dan representasi matematik (mathematical representation)". Berdasarkan pernyataan tersebut, salah satu kompetensi yang harus dipenuhi ialah kemampuan representasi matematik. Representasi adalah suatu model atau bentuk yang digunakan untuk mewakili suatu situasi atau masalah agar dapat mempermudah pencarian solusi

$$
\text { Menurut Ramziah (2016:2), }
$$

"Representasi matematis merupakan 
bantuan dalam memahami konsep dan prinsip matematika secara mendalam guna penyederhanaan penyelesaian masalah matematika. Dengan demikian, kemampuan representasi merupakan kemapuan yang sangat penting yang harus dikuasai oleh siswa, karena sebelum siswa dapat memecahkan masalah siswa harus tahu permasalahan yang harus dipecahkan dan bagaimana menggambarkan permasalahan tersebut. Ragam representasi yang sering digunakan dalam mengkomunikasikan matematika antara lain tabel, gambar, grafik, ekspresi atau notasi matematis, serta menulis dengan bahasa sendiri.

Dalam pembelajaran matematika
guru harus memperhatikan
keseimbangan antara proses tindakan dan prosesberpikir siswa. Guru harus dapat menumbuhkan kesadaran siswa dalam melakukan aktivitas pembelajaran sehingga siswa tidak hanya memiliki keterampilan melakukan sesuatu tetapi harus memahami mengapa aktivitas itu dilakukan. Salah satu pendekatan pembelajaran yang dapat membantu memenuhi tuntutan tersebut adalah Pendekatan Keterampilan Metakognitif dimana dalam prosesnya pendekatan ini meliputi kegiatan menanamkan kesadaran kepada siswa suatu proses bagaimana merancang, memonitor, dan mengevaluasi aktivitas yang dilakukan untuk menentukan solusi dari suatu permasalahan.

Menurut Susilawati

Pendekatan Keterampilan Metakognitif terdiri dari tiga tahap:

a) Tahap Diskusi Awal

Tahap ini diawali dengan penanaman konsep yang dimulai dengan menjawab pertanyaanpertanyaan yang ada di dalam bahan ajar, LKS, dan soal-soal evaluasi. Siswa dibimbing untuk menanamkan kesadaran dan keyakinan dengan bertanya pada diri sendiri saat menjawab pertanyaan - pertanyaan yang diajukan bahan ajar, sehingga siswa mempunyai keyakinan bahwa mereka dapat menyelesaikan permasalahan yang diberikan. Pada akhir pemahaman, siswa sadar apa yang harus dilakukannya, bagaiman melakukan bagian yang belum dipahami, pertanyaan yang timbul, dan bagaiman usaha mencari solusinya.

b) Tahap Kemandirian

Pada tahap ini siswa bekerja secara mandiri untuk menyelesaikan soalsoal yang diberikan. Guru berkeliling kelas memberikan feedback secara individual, feedback metakognisi akan menuntun siswa untuk memutuskan perhatian pada kesalahannya dan memberikan petunjuk agar siswa dapat mengoreksinya sendiri. Guru membantu mengawasi cara berpikirnya, tidak langsung memberikan jawaban yang benar ketika siswa membuat kesalahan.

c) Tahap Refleksi dan Penyimpulan Pada tahap ini refleksi tidak hanya dilakukan oleh guru, tetapi juga oleh siswa. Refleksi yang dilakukan oleh guru bertujuan sebagai pemantapan konsep dan aplikasi konsep lebih luas, sehingga belajar siswa menjadi lebih bermakna. Sedangkan refleksi yang dilakukan siswa lebih mengarah pada apa yang telah mereka pahami setelah medapatkan pembelajaran, sehingga memungkinkan siswa untuk dapat mengaplikasikan konsep tersebut dalam masalah yang lebih luas. 
- Berdasarkan kajian pustaka dan uraian di atas, hipotesis dalam penelitian tindakan kelas ini adalah kemampuan representasi matematis siswa kelas XII TEK A SMK Negeri 1 Cimahi dapat meningkat dengan menggunakan pendekatan keterampilan metakognitif.

\section{PELAKSANAAN}

Penelitian ini dilaksanakan mulai tanggal 15 Maret 2018 sampai 1 September 2018 pada tahun akademik 2018/2019 di SMK Negeri 1 Cimahi Kota Cimahi dengan subjek penelitian adalah siswa-siswi kelas XII TEK A dengan jumlah siswa 36 orang terdiri dari 19 orang laki-laki dan 17 orang perempuan. Metode yang digunakan adalah analisis deskriptif komparatif yaitu membandingkan nilai tes awal dan tes antar siklus. Penelitian tindakan kelas ini dilakukan secara bertahap. Adapun tahap pelaksanaan penelitian sebagai berikut :

\section{Perencanaan}

Langkah-langkahnya sebagai berikut:
a) Membuat Rencana Pembelajaran termasuk membuat skenario pembelajaran.

b) Menyiapkan Lembar Observasi.

c) Membuat alat evaluasi untuk mengetahui keberhasilan siswa.

\section{Tindakan}

\section{Pendahuluan}

a) Guru membuka pembelajaran dengan mengarahkan siswa untuk berdoa

b) Guru menyemangati siswa dengan meyakinkan bahwa materi yang diajarakan banyak kegunaannya dalam kehidupan sehari-hari

c) Guru mengecek kehadiran siswa

d) Guru mengingatkan siswa tentang materi sebelumnya, kemudian guru menyampaikan

tujuan

pembelajaran

\section{Kegiatan Inti}

a) Guru membagikan LKS kemudian Peserta didik mengamati permasalahan LKS tersebut

b) Guru membimbing siswa untuk berpikir dan merumuskan pertanyaan mengenai materi integral tentu

c) Guru membimbing siswa untuk mengerjakan soal secara mandiri, kemudian guru berkeliling kelas memberikan feedback secara individual berupa arahan

d) Guru membantu mengawasi cara berpikir siswa, tidak langsung memberikan jawaban yang benar ketika siswa membuat kesalahan

e) Guru memberikan pertanyaan kepada siswa tentang materi yang sedang dipelajari, kemudian guru memberikan arahan agar siswa memahami konsep dan aplikasi konsep tersebut secara luas.

\section{Penutup}

a) Guru membimbing siswa untuk menyimpulkan apa yang telah siswa pelajari dikelas melalui beberpa pertanyaan

b) Guru menutup pembelajaran dengan penegasan kembali kesimpulan yang telah didapatkan siswa dan memberikan tugas berupa soal-soal integral tentu

\section{Observasi}

Kegiatan terhadap tindakan yang meliputi:

a) Kemandirian siswa dalam bekerja

b) Mampu melaksanakan tugas yang diberikan secara efektif.

c) Siswa aktif mengajukan pertanyaan atau tanggapan. 
d) Aktif dalam menggunakan berbagai sumber untuk membantu dalam memecahkan masalah.

\section{Refleksi}

Perenungan dilakukan untuk mengkaji keberhasilan dan kelemahan tindakan. Kegiatan yang dilakukan dalam perenungan meliputi:

a) Analisis data yang diperoleh untuk menentukan langkah tindakan yang lebih pada pembelajaran selanjutnya.

b) Mengevaluasi proses dan hasil belajar siswa.

Mengevaluasi aktivitas guru dalam kegiatan belajar mengajar.

\section{Metode Pengumpulan Data}

\section{Teknik Pengumpulan Data}

Tes dan Lembar Observasi

2. Alat Pengumpul Data Butir Soal Tes Tertulis Bentuk Uraian

3. Sumber Data
a. Nilai awal
b. Nilai tes siklus I
c. Nilai tes siklus II (nilai akhir)

\section{HASIL DAN PEMBAHASAN}

Penelitian tindakan kelas ini dilaksanakan karena mengingat kondisi siswa yang ternyata masih banyak mengalami kesulitan diantaranya kurang memahami konsep luas dalam integral, kesulitan terletak pada kemampuan merepresentasikan masalah misalnya merepresentasikan suartu fungsi ke dalam sebuah grafik, cara mencari daerah yang dibatasi oleh suatu kurva atau lebih dan tidak bisa mengkunikasikan atau menjelaskan pemecahan masalah secara verbal. Kondisi seperti tersebut tentunya tidak dapat dibiarkan dan harus ada evaluasi dan penelitian untuk dapat meningkatkan kemampuan siswa. Pada penelitian tindakan kelas ini, akan dilaksanakan upaya-upaya pembelajaran guna mengingkatkan hasil belajar siswa terutama pada materi integral.

Pada tahap awal, dilaksanakan pretest dengan memberikan soal integral tentu. Adapun data terebut sebagai berikut;

Tabel 1

Data Pretes Siswa Kelas XII TEK A

\begin{tabular}{lll}
\hline No & \multicolumn{1}{c}{ Data } & Hasil Pretest \\
\hline $\mathbf{1}$ & Jumlah & 1363,33 \\
$\mathbf{2}$ & Rata-rata & 42,60 \\
$\mathbf{3}$ & $\begin{array}{l}\text { Standar } \\
\text { deviasi }\end{array}$ & 10,04 \\
\hline
\end{tabular}

\section{Tindakan Siklus I}

\section{Pertemuan 1}

Dalam perencanaan awal guru menyusun skenario pembelajaran dalam bentuk RPP dan membuat LKS. RPP yang dibuat untuk siklus 1 terdiri dari dua pertemuan pada materi "Jumlah Rieman dan definisi integral tentu", dengan menggunkan pendekatan keterampilan metakognitif dan dilakukan dengan metode tanya jawab klasikal, serta memiliki indikator: (1)Memahami konsep jumlah rieman dan integral tentu dan (2)Menentukan luas dari suatu daerah yang dibatasi oleh suatu kurva. Selain itu, peneliti juga membuat lembar observasi yang ditujukan pada guru dan siswa dimana aspek yang diamati didasarkan pada langkah-langkah pembelajaran pada RPP, menyiapkan lembar jurnal refleksi dan merancang perangkat evaluasi untuk tes siklus I. 
Dalam pelaksanaan selanjutnya guru memberikan LKS pada setiap siswa, kemudian guru meminta siswa untuk membaca LKS secara keseluruhan dan mengikuti instruksinya. Setelah itu, siswa dipersilakan mengerjakan tahap demi tahap dalam LKS. Guru memberikan bimbingan untuk bagian yang sulit siswa pahami, pada tahap diskusi awal guru menggambarkan sebuah kurva dan menuntun siswa untuk mencari luas darah tersebut dengan jumlah riemen. Dalam kegiatan ini ada beberapa siswa yang tidak mengikuti instruksi dari guru, namun sebagian besar melakukannya sesuai dengan LKS. Setelah itu, siswa melanjutkan mengerjakan soal secara mandiri, kemudian guru berkeliling kelas untuk memberikan feedback secara individual, berupa bertanya dan menjawab pertanyaaan siswa dan memberikan arahan seperlunya serta memberikan penilaian untuk LKS. Dari hasil ini dapat diketahui tingkat kemampuan peserta didik dalam menjawab soal integral pada siklus I. Berdasarkan hasil pekerjaan siswa, lalu diadakan pembahasan soal secara bersama. Hai ini dimaksudkan agar siswa dapat benar-benar memahami pemecahan soal-soal jumlah rieman dan integral tentu.

\section{Pertemuan 2}

Guru memberikan LKS pada setiap siswa, kemudian guru meminta siswa untuk membaca LKS secara keseluruhan dan mengikuti instruksinya. Setelah itu, siswa dipersilakan mengerjakan tahap demi tahap dalam LKS. Guru memberikan bimbingan untuk bagian yang sulit siswa pahami, pada tahap diskusi awal guru meminta siswa untuk menjawab pertanyaan pada tahap ini. Dalam kegiatan ini siswa mampu menjawabnya dengan benar karena jawaban yang diharapkan ada rumus luas persegi panjang. Setelah itu, siswa melanjutkan mengerjakan soal secara mandiri, kemudian guru berkeliling kelas untuk memberikan feedback secara individual, berupa bertanya dan menjawab pertanyaaan siswa dan memberikan arahan seperlunya serta memberikan penilaian untuk LKS. Dari hasil ini dapat diketahui tingkat kemampuan peserta didik dalam menjawab soal integral pada siklus I pertemuan ke-2. Berdasarkan hasil pekerjaan siswa, lalu diadakan pembahasan soal secara bersama. Hai ini dimaksudkan agar siswa dapat benar-benar memahami pemecahan soal- integral tentu yang dibatsi oleh suatu kurva Pada tahap ini juga siswa diberikan tes evaluasi untuk silkus pertama.

\section{Evaluasi}

Dari pelaksanaan siklus I pertemuan pertama memiliki rata-rata yang rendah yaitu 48, 65 sedangkan pada pertemuan kedua rata-ratanya meningkat menjadi 52,19 artinya keterliibatan dan usaha siswa dalam mempelajari materi telah mengalami peningkatan. Sementara hasil tes pada siklus pertama rata-rata nilai siswa mencapai 52, 19 artinya kemampuan siswa dalam merepresentasikan masalahpun mengalami kemajuan dibandingkan pada saat sebelum diberi tindakan.

Sedangkan pada pertemuan pertama di siklus II rata-rata siswa mencapai 68,96. Hasil ini menunjukan peningkatan darii siklus I yang rataratanya hanya mencapai 62,81 . Pada pertemuan ke- 2 di siklus dua peningkatan kembali terjadi hingga rata-rata nilai LKS siswa mencapai 78,85, nilai ini menunjukan bahwa siswa terus mengalami peningkatan dalam keaktifan dan partisipasi kelas 
khususnya dalam mengisi LKS dan soalsoal mandiri. Nilai tes pada siklus II mencapai rata-rata 58, 59 yang artinya juga mengalami peningkatan dari yang awalnya 52,19. Hal ini menunjukan bahwa pendekatan pembelajaran yang digunakan cukup efektif untuk digunakan.

Tabel 2

Data Pretest dan Postest Siswa Materi Integral Tentu

\begin{tabular}{cccc}
\hline No & Data & $\begin{array}{c}\text { Hasil } \\
\text { Pretest }\end{array}$ & $\begin{array}{c}\text { Hasil } \\
\text { Posttest }\end{array}$ \\
\hline $\mathbf{1}$ & Jumlah & 1363,33 & 1810,00 \\
$\mathbf{2}$ & Rata-Rata & 42,60 & 56,56 \\
$\mathbf{3}$ & Standar Deviasi & 10,04 & 12,88 \\
\hline
\end{tabular}

\section{Refleksi}

Dari hasil pengamatan selama kegiatan siklus I dan siklus II, kegiatan pembelajaran dengan menggunakan pendekatan keterampilan metakognitif memilki kelebihan/ keberhasilan sebagai berikut;

(a) Terdapat peningkatan kemampuan representasi siswa setelah dilakukan proses belajar dengan pendekatan metakognitif.

(b) Adanya suasana kegiatan belajar mengajar lebih kondusif sehingga dapat menambah keberanian siswa untuk bertanya pada guru dan bekerja secara mandiri.

(c) Dari tabel diatas ditunjukan bahwa rata-rata nilai pretest siswa adalah 42,60 dan nilai postest mencapai 56,56 artinya terdapat peningkatan nilai dari pretest ke postest sebesar 13,96. Ini menunjukan bahwa penerapan pendekatan keterampiilan metakognitif siswa dapat meningkatkan kemampuan matematik siswa khususnya kemampuan representasi matematis. Dengan demikian dapat disimpulkan bahwa kemampuan representasi matematis siswa kelas XII TEK A SMK Negeri 1 Cimahi dapat meningkat dengan menggunakan pendekatan keterampilan metakognitif.

\section{SIMPULAN}

Berdasarkan hasil penelitian yang dilakukan, dapat disimpulkan bahwa kemampuan representasi matematis siswa kelas XII TEK A SMK Negeri 1 Cimahi dapat meningkat dengan menggunakan pendekatan keterampilan metakognitif. Hal ini dapat dilihat dari adanya peningkatan nilai rata-rata dalam perolehan hasil belajar siswa. Demikian pula, ada peningkatan respon yang positif terhadap pembelajaran berupa partisipasi siswa dalam mengisi LKS dengan sungguhsunguh yang ditunjukan dengan semakin meningkatnya nilai rata-rata LKS dari siklus ke siklus.

\section{SARAN}

Berdasarkan data yang diperoleh, yang dikaitkan dengan hasil belajar siswa maka saran yang diberikan diantaranya adalah:

1. Guru diharapkan dapat menciptakan kegiatan pembelajaran yang aktif, kreatif dan menyenangkan serta menumbuhkan kemandirian siswa.

2. Guru perlu memberikan perhatian dan motivasi bagi peserta didik yang mengalami kesulitan dalam belajar.

3. Pendekatan

Keterampilan Metakognitif dapat diterapkan pada materi lain dan tidak menutup kemungkinan pada mata pelajaran yang 
lain serta mengasah kemampuan berpikir selain kemampuan representasi matematis.

\section{DAFTAR PUSTAKA}

Hamzah (2000). Pembelajaran Matematika I. Jakarta: Bumi Aksara Hudoyo, H. (1988). Mengajar Belajar Matematika. Jakarta: Depdikbud Dirje Dikti Proyek Pengembangan Lembaga Pendidikan Tenaga Kependidikan.

Maryanti, E. (2012). Peningkatan Literasi Matematik Siswa melalui Pendekan Metacognitive Guidance. Tesis pada Jurusan Pendidikan Matematika UPI Bandung: tidak diterbitkan.

Murni, A. (2012) . Peningkatan Kemampuan Representasi Matematis Siswa SMP melalui Pembelajaran Metakognitif dan Pembelajaran Metakognitif Berbasis Soft Skill. Jurnal Pendidikan, 4(2). PP 96-107.

Nurasyiyah, D. A. (2104). Pendekatan Metakognitif dalam Pembelajaran Matematika untuk Pencapaian Kemampuan Koneksi dan Pemecahan Masalah Matematik Siswa SMA. JMP, 6(2). PP 115-125.

Ramziah, S. (2016). Peningkatan Kemampuan Representasi Matematis Siswa Kelas X2 SMAN 1 Gedung Meneng Menggunakan Bahan Ajar Matriks Berbasis Pendekatan Saintifik. Jurnal Pendidikan Matematika STKIP Garut, 8(3). PP 110.

Suryana, A. (2012). Kemampuan Berpikir Matematis Tingkat Lanjut (Advanced Mathematical Thinking) dalam Mata Kuliah Statistika Matematika. Makalah dipresentasikan dalam Seminar Nasional Matematika dan Pendidikan Matematika pada tanggal 10
November 2012 di Jurusan Pendidikan Matematika FMIPA UNY.

Susilawati, W. (2012). Belajar \& Pembelajaran Matematika. Bandung: Insan Mandiri.

Syah, Muhibbin. (2010). Psikologi Pendidikan dengan Pendekatan Baru. Bandung: Remaja Rosda Karya

Ruseffendi, E. T. (1991). Penilaian Pendidikan dan Hasil Belajar Siswa Khususnya dalam Pengajaran Matematika. Bandung: Tidak diterbitkan.

Soejadi. (2000). Kiat Pendidikan Matematika di Indonesia. Jakarta: Dirjen Dikti Depdikbud.

Undang-undang RI Nomor 20 tahun 2003 tentang Sistem Pendidikan Nasional. 